\title{
On amarāvikkhepa
}

\section{HatA Masatoshi}

(0) In the Brahmajālasutta, which is the first sutta of the Dighanikāya, sixty-two kinds of views are listed up. All of them are heretical views from the standpoint of Buddhism, and they can also be classified into ten theories. Amarāvikkhepa is the name of the theory which is presented fourthly of them. In hitherto studies, the comparison between its content and non-answering of the Buddha has often been made. But I'm afraid several important researches about the theory have not been made, e. g. fixing the meaning of its title and analyzing its content in use of other sources than the Pāli Brahmajālasutta. In this paper, I intend to make the above-mentioned researches.

(1.1) Standard Pāli dictionaries list the following meanings in the entry of amara $\bar{a}-$ vikkhepa. CPD s.v.: prob. "eel-wriggling" for "shuffling or evasive answers"; PED s.v.: eel-wobbler, one who practices eel-wriggling. Besides, in the translations of the Brahmajālasutta, this word was translated as endless equivocation ${ }^{1)}$. Although the meaning of the vikkhepa, which is the latter member of the compound, has been settled ${ }^{2)}$, the problem exists in the meaning of the former, amara $\bar{a}$, which has not been given a suitable meaning in any Pāli or Sanskrit dictionaries.

(1.2) Then, I will investigate the description presenting the advocator of amarāvikkhepa in the Brahmajălasutta and its parallels.

Pāli: "O monks, some recluses or brāhmaṇas are amarāuikkhepikas, and when they are asked about this or that, they engage in amarävikkhepa, which is the confusion of words (vācāvikkhepa), for four reasons." (DN I, p. 24)

From the bold-faced part, we can see that amarāvikkhepa is paraphrased as "the confusion of words." Besides, in a different sutta, the king Ajātasatthu summarizes the theory of Sañjaya Belatthiputta, which corresponds to amarāvikkhepa, as confusion (vikkhepa) ${ }^{3)}$. This statement justifies the analysis of the compound into amara-vikkhepa, and suggests that the former member of the compound, amara $\bar{a}$, is not necessarily indispensable. 
Next, this sutta has two Tibetan parallels, both of which belong to the Sarvāstivāda tradition $^{4)}$. Descriptions corresponding to the above Pāli are as follows.

Tib1: "O monks, for four reasons, some recluses or brāhmaṇas consider the past, do not throw a deity away, and they disturb with the wind of word(s) when they are asked the question about not throwing a deity away. "( $\$ 135)$

The bold-faced words (Tib.: lha mi spon la), which correspond to Pāli amarāvikkhepa, can be restored to Skt. *amara-aviksepa. Hence the Tibetan translator seems to have interpreted the members of the compound as amara and aviksepa. But this is only an interpretation of the translator. From this translation, we can presume that the original Sanskrit text would have the word amarāviksepa. Actually, extant Sanskrit fragments corresponding to this part justify this presumption ${ }^{5)}$. In addition, I would like to note that both of the Sanskrit and Tibetan versions preserve some different contents from Pāli version, such as "a question about not throwing a deity away (amarāvikṣepe praśnam)."

Tib2 has the similar content to that of Tib1. But in Tib2, there is also one expression which can be restored to Skt. "mara-viksepa ${ }^{6)}$, which tells us the confusion of textual transmission. Similar phenomena can also be seen in the Sanskrit fragment ${ }^{7)}$. Such confusion is considered to show that the meaning of the word had already been unknown at an earlier time of the transmission.

Lastly, I will examine other parallels of the Brahmajälasutta and the Abhidharma texts which preserve the description of amarāviksepa. Since Chinese parallels of the sutta have no corresponding words to amarāvikkhepa, I need not examine the parallels here. The Yogācārabhümi calls this theory amarāvikșepavāda, and its Tibetan and Chinese translations run as follows: Tib: the theory of not throwing a deity away (lha mi spon ba; = Skt. *amara-aviksepa); Chin.: the theory which has no death and has confusion ${ }^{8)}$. And the Tibet-

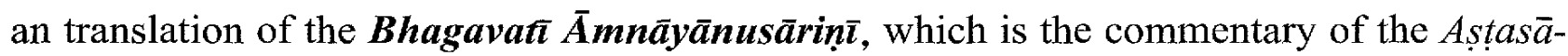
hasrikā Prajñāpāramitā, calls this theory "rnam par g-yen ba smra ba," which may be restored to Skt. *viksepa-vāda ${ }^{9)}$.

By examining the parallel texts of the Brahmajalasutta, the three following points are clarified. 1. The extant Sanskrit and Tibetan texts, which belong to the Sarvāstivādins, preserve the word amarāvikșepa which corresponds to Pāli amarāvikkhepa. 2. Since the former members of the compound sometimes alter between amar $\bar{a}$ - and amara-, it is probable that the meaning of this part was unknown to the transmitter of the texts. 3. Its latter mem- 
ber, vikkhepa / viksepa, is consistent among the texts, and some texts call the amarāvikkhepa just vikkhepa.

(1.3) Next, I will observe the way of explaining this word in the Pāli commentary and the Abhidharma texts.

Pāli commentary: "(i) Amarā means that it does not die. ... amarāvikkhepa means disturbance with an immortal (, that is, endless) view or word. Its possessors are amarāvikkhepikas. (ii) There is another way (of comment). Amarā means a kind of fish. Since it swims up and down in the water, it is impossible to catch it. Just like it, because this theory also runs here and there, it is impossible to catch it. Therefore, it is called amarāvikkhepa." (Sv I, p. 115)

Thus, two kinds of explanations are given. It is evident that the common translation "eel-wriggling" is based on the interpretation (ii). On the other hand, less common interpretation (i) explains that amara $\bar{a}$ has a feminine case because it qualifies the feminine noun, ditțhi or $v \bar{a} c \bar{a}$. This interpretation agrees with the fact that the compound $v \bar{a} c \bar{a} v i k k h e-$ $p a$ is used in the Pāli text. Therefore, as far as we follow the usages in those texts, (i) seems more reasonable than (ii).

The Chinese translation of the *Abhidharma Mahävibhäșā (translated by Hsüan-tsang), which is an Abhidharma text of the Sarvāstivādins, gives an explanation on amarāviksepa as follows: Regarding the four kinds of the immortal theories along with disturbance (不 死矯亂論), ... “I hear that there is the following theory in a heretical treatise: 'If he can answer an immortal deity's question without disturbance (不死天無亂問), he will be born as the deity. If he can not, he will not. ... In regards to the immortal question without disturbance (不死無亂問), the heretics disturb (his opponents) in use of words (以言矯亂).” (T. 27, p. 998a)

In this statement, at first, we can see the explanation that the phrase "an immortal deity ... without disturbance (不死 [天] 無亂), " which corresponds to amarāvikșepa, is related to the "question (問)." This is the interpretation which follows the Sarvāstivāda text such as Tib1, 2, and results from the difference of the original texts from the Pâli version. Next, it seems that the translator Hsüan-tsang translated differently on the above bold-faced words. But it must be due to his interpretation, and the phrases must have been identical in the original Sanskrit text. ${ }^{10)}$

(2) In the preceding chapter, I examined the way of explanation of amarāvikkhepa. 
I will show the content of amarāvikkhepa described in various texts.

(2.1) First of all, the Pāli Brahmajalasutta lists four variations of the theory ${ }^{11)}$. And in all of the variations, the following statement is made. "I do not think so, nor do I think in that way. I do not think in another way, either. I do not think it is not, nor do I think it is not no. ${ }^{12)}$ " This would be the well-known content of this theory.

Next, as to Tib1 and Tib2, almost the same grounds of the theory as that of Pâli are presented. On the other hand, regarding the content of insistence, there are no clear statements in these texts. Only one variation which follows the fourth ground has a similar content to the Pāli's. "If someone comes to me, thinking that the world beyond exists, and asks me if the world beyond exists or not, I will reply to him that the world beyond exists ${ }^{13)}$." But this statement is not entirely same as the Pāli's. The biggest difference between them is as follows: In Pāli, the advocator of amarāvikkhepa does not give any definite answers; In Tib1, 2, he answers just as he is asked. In other words, amarāviksepa in Tib means a behaviour like a yes-man ${ }^{14)}$.

(2.2) Then, I would like to investigate the description in the Abhidharma texts.

As for the Mahāvibhāsā, the grounds of the theory are almost similar to that of Tib1, 2. But in the Mahāvibhāsă, various kinds of persons are presented as the advocators of amarāvikșepa. For example, (1) someone who can not say a word of disturbance because of his dullness, (2) someone who does not oppose his opponent's theory for the sake of his own rebirth in the heaven, and (3) for the sake of keeping friendship with the opponent. Therefore, as far as the Mahāvibhāṣa explains, amarāvikṣepa means non-insistence for some reasons.

Lastly, I will show the description of the Yogācārabhümi in short. In this text, the attitude of the advocator is summarized as giving no definite answers. The grounds of the theory are explained in four types: (1) non-purity of the heart, (2) pride in his own knowledge, (3) fear for having a wrong view or for an opponent's inquiry, (4) fear for opponent's inquiry because of his dullness. Following types (1) - (3), the advocators try to change the subjects (a kind of $v \bar{a} c \bar{a} v i k s$ epa), and following (4), the advocator tries to ask his opponent again or to accept the opponent's opinion (kinds of vācāvikșepa). Therefore, the explanation of amarāvikșepa in the Yogācārabhūmi is consistent in meaning "giving no definite answers "(spaștam na vyākaroti; Bhattacharya [ed.], p. 149). But it no longer has the famous expression ("I do not think so ...") which Pāli does. 
(3) I would like to conclude this paper by summarizing the above. Following the descriptions of the Pāli Brahmajālasutta, amarāvikkhepa means giving no definite answers, with saying "I do not think so, nor do I think in that way. ..." But in the scriptures of the Sarvāstivādins, this way of answering became only one variation of amarāvikșepa, which also means a behaviour like a yes-man. Moreover, the Abhidharma texts of later periods come to interpret the feature of amarāviksepa simply as giving no definite answers. The emergence of such diverse interpretations may well be grounded on the diversity of the original scriptures (sutta, sütra) of each sect. But the biggest reason is assumed to be that the meaning of amarāviksepa was not understandable for the transmitters of the texts.

As for the original meaning of amarāvikkhepa / amarāviksepa, it mattered what amarā meant. And in the texts held above, we have seen several explanations, such as "immortal (endless) word" (amarā vāca) , "a kind of fish," or "a deity."

Translating amarāoikkhepa in consideration of the above situations, the common translation "eel-wriggling" is not suitable. Judging from the explanation of the Pāli commentary which interprets amara as a kind of fish, amarā is a fish swimming swiftly, and a wriggling eel is not intended. On the other hand, the Chinese translation "the immortal theory along with disturbance (不死矯亂論), ” which was popular especially in old Japanese translations, is not suitable as an usual translation, for we must consider that amarāvikșepa was translated in two ways, "the immortal theory along with disturbance (不死矯亂論)" and "the immortal one without disturbance (不死無镝) ” within the same text.

Selecting the proper translation of the word, it is the best way to adopt the first interpretation of the Pāli commentary: amara $\bar{a} \bar{a} c \bar{a}$, which matches the description of the Pāli text, and does not contradict that of the Sarvāstivādins. Therefore, amarāvikkhepa is to mean "disturbance with endless words." Thus "endless equivocation," which was used in an English translation of the Brahmajālasutta, is considered as the best translation I can suggest at present.

1) Bhikkhu Bodhi, The Discourse on the All-Embracing Net of Views, Kandy, 1978, p. 71; P. Fuller, The Notion of ditthi in Theravāda Buddhism, London \& New York, 2005, p. 161.

2) PED s.v. vikkhepa: 1. disturbance; 2. perplexity, confusion.

3 ) DN I, p. 59, 11. 9-11.

4) I will use the abbreviation Tib1, Tib2 to signify the two Tibetan versions. Tib1 exists as an individual sūtra in the Tibetan Tripitaka. Weller's edition of it has been published. (F. Weller, Brahmajālasūtra: Tibetischer und mongolischer Text, Leipzig, 1934.) Tib2 is the sütra quoted in 
the Śamathadeva's commentary of the Abhidharmakośabhāsya. Cf. Y. Honjō, A Table of ĀgamaCitiations in the Abhidharmakosia and the Abhidharmakosopayyikā, part I, Kyoto, 1984, no. [3050]. 5 ) SHT (III) Kat.-Nr. 803V5: $a \bigcirc \operatorname{marāvi}[k](s)$ e (pi) kā amarāviksepe praśnam prștāh vā [cavi] ksepam $\bar{a}[s r t]$ ya.. $\quad 6$ ) 'chi ba dan rnam par g-yen ba (Derge [ed.], Ju 149a3) SHT (III) Kat.-Nr. 803V6: amaravikșepikäh amaravi $[\boldsymbol{k}] \underline{s}[\boldsymbol{e}]$ pe prśnam prọ $(t) \bar{a}[h v](\bar{a} c \bar{a}) v i \bigcirc$ $[k](s)[e p](a m) \quad 8$ ）不死矯亂論 (T. 30, p. 310c) 9 ) Cf. H. Isoda, "On "the Sixty-two Heretical Doctrines" Summarized in the Amnāyānusārinī," in Indian Thoughts And Buddhist Culture (Fs. J. Imanishi), Tokyo, 1996, pp. (343)-(353).

10) The Yogācārabhümi also has the description explaining amarāviksepa. Regrettably, its Sanskrit text is lost in the published edition. (V. Bhattacharya [ed.], The Yogāeārabhūmi of Ācārya Asañga, part I, Culcutta, 1957, p. 149) But we can restore the Sanskrit text from Tibetan and Chinese translations. (Tib.: Derge [ed], Tshi 75a; Chin.: T. 30, p. 310c) Concerning the explanation of amarāvikșepa, both of the translations preserve a different content from that of the Mahāvibhaș $\bar{a}$. But for my argument, there is nothing important in the part. $\quad 11$ ) $1-3$ : He (the advocator of amarāvikkhepa) does not know what is right and wrong. If he answers without any knowledge, he will be distressed (1)

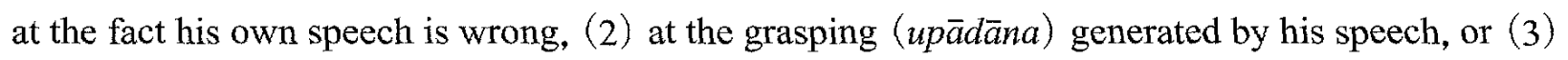
at his opponent's inquiry. Fearing such distress, he insists on amarāvikkhepa. 4: He is dull and stupid. So when he is asked about the existence of the world beyond and so on, he insists on amara $\bar{a}-$ vikkhepa. 12) evam pi me no. tathà ti pi me no. añnathà ti pi me no. no ti pi me no. no no ti pi me no. (DN I, p. 25) 13) Taking the same pattern, the question of the opponent follows, such as "the world beyond does not exists," "both exists and not exists," and so on,; Cf. SHT (III) Kat.-Nr. 803V2, V3. 14) Besides, we can find the description about amarāvikșepa in a parallel of the Brahmajālasutta, i.e., the Chinese Dirghāgama, too. It has the similar content to that of Tib1, 2. But it is not clear whether it intends the behaviour of a yes-man or not.

〈Key words〉 amarāvikkhepa, amarāvikșepa, amarā, eel

(Part-time Lecturer, Shuchiin University) 